\title{
Complete larval development of the crab Ilia nucleus (Linnaeus, 1758) (Decapoda: Brachyura: Leucosiidae) reared under laboratory conditions
}

\author{
CÁTIA BARTILOTTI ${ }^{1}$, JUAN IGNACIO GONZÁLEZ-GORDILLO ${ }^{2}$ \\ and ANTONINA DOS SANTOS ${ }^{1}$ \\ ${ }^{1}$ Instituto Nacional de Recursos Biológicos, IPIMAR, Av. de Brasília, s/n. 1449-006 Lisboa, Portugal. \\ E-mail: cbartilotti@ipimar.pt \\ ${ }^{2}$ CACYTMAR - Universidad de Cádiz, Avd. República Saharaui, s/n., E-11510 Puerto Real, Cádiz, Spain.
}

\begin{abstract}
SUMMARY: The complete larval development of the crab Ilia nucleus (Linnaeus, 1758) reared under laboratory conditions was obtained. The four zoeal stages and the megalopa are described and illustrated in detail. The larval features observed in I. nucleus fit into the characteristics of the family proposed by Rice (1980) for the zoeal stages and by Quintana (1986) for the megalopa. The morphological characters of larval stages of I. nucleus are compared with previous descriptions, and with those of other known larvae of Leucosiidae (only for subfamilies Ebaliinae and Leucosiinae). The present work supports the hypothesis that the subfamily Ebaliinae is a heterogeneous group. For the correct identification of a zoeal stage of a leucosiid crab, besides counting the number of setae on maxilliped exopods, the antennule as well as the pereiopods development should be used as additional characters.
\end{abstract}

Keywords: Crustacea, Decapoda, zoeal stages, megalopa, larval morphology, laboratory rearing, Ilia nucleus.

RESUMEN: Desarrollo larvario completo del Cangrejo Ilia nucleus (Linnaeus, 1758) (Decapoda: Brachyura: LEUCOSIIDAE) EN CONDICIONES DE LABORATORIO. - En este trabajo se describe el desarrollo larvario completo del cangrejo Ilia nucleus (Linnaeus, 1758) a partir de larvas obtenidas en laboratorio. La fase larvaria comprende cuatro estados de zoea y uno de megalopa, todos ellos se describien e ilustran en detalle. Se constata que los caracteres larvarios observados en $I$. nucleus se ajustan de modo general a las características típicas de la familia Leucosiidae propuestos por Rice (1980) para las zoeas y por Quintana (1986) para las megalopas. La morfología larvaria de I. nucleus se compara además con descripciones anteriormente realizadas para esta especie, así como con las de otras larvas conocidas de Leucosiidae (subfamilias Ebaliinae y Leucosiinae) poniéndose de manifiesto la heterogeneidad morfológica de la subfamilia Ebaliinae. La correcta identificación de zoeas de un cangrejo leucosiideo requiere, además de conocer el número de setas de los exopoditos de los maxilipedos, el tipo de desarrollo de la anténula o el desarrollo de los pereiopodos.

Palabras clave: Crustacea, Decapoda, zoea, megalopa, morfología larvaria, cultivos en laboratorio, Ilia nucleus.

\section{INTRODUCTION}

The family Leucosiidae Samouelle, 1819 is represented in northeastern Atlantic and Mediterranean waters by 17 species (d'Udekem d'Acoz, 1999), but the larval development is only known for six of these (González-Gordillo et al., 2001). Ilia nucleus
(Linnaeus, 1758) sensu lato is a leucosiid crab occurring in the Atlantic Ocean from southeast Spain to Cape Verde islands, and in the Mediterranean Sea (d'Udekem d'Acoz, 1999). Previous larval descriptions for this species are known from plankton-collected material and laboratory-reared larval stages (Cano, 1891; Boraschi, 1921; Bourdillon-Casanova, 
1960; Heegard, 1963), although these do not make a complete larval development description according to modern standards.

Cano (1891) described the first and second zoeal stages as well as the megalopa of I. nucleus from laboratory-reared material (females collected in the Gulf of Napoli), but the first two zoeal stages were ascribed to Nautilograpsus. Later, Boraschi (1921) presented a telson of the first zoea of Nautilograpsus minutus collected from the plankton along the Italian coast (collection sites: Quarto dei Mille in Genova, Ligurian Sea, and Palermo in Sicily, Tyrrhenian Sea) citing Cano's description (1891), and keeping the name assigned by the previous author. In the same year, Caroli (1921) perceived Cano's mistake. He captured some late zoeae of what he thought to be Planes minutus (as Nautilograpsus minutus), and reared these in the laboratory. After the moult, a small brachyuran crab with all characters of I. nucleus was obtained, leading him to suppose that Cano (1891) described both species, I. nucleus and N. minutus, but during the plate preparation he presented the zoeal description of I. nucleus in the place of $N$. minutus, with the correct figure for the megalopa, and vice versa. Bourdillon-Casanova (1960) described the first three zoeal stages of I. nucleus from plankton-captured larvae and discussed her results with previous larval descriptions of this species. She concluded that Boraschi (1921) had ignored a correction made by Cano in 1893 to his own mistake. Bourdillon-Casanova (1960) made the same assumptions about the zoeal description of Cano (1891): the megalopa attributed to I. nucleus was correctly identified, but the zoeal stages description attributed to $I$. nucleus belong to N. minutus. Later, Heegard (1963) presented a description of the first zoea of I. nucleus, from laboratory-reared material.

The present study describes in detail the four zoeal stages and the megalopa of I. nucleus from laboratory-reared material. The morphological characters of larval stages of I. nucleus are compared with previous descriptions, and with those of other known larvae of Leucosiidae (only for the subfamilies Ebaliinae and Leucosiinae).

\section{MATERIALS AND METHODS}

Three ovigerous females of Ilia nucleus were caught on March 2003 with a benthic trawl at $6 \mathrm{~m}$ depth in Valdelagrana Beach, Cádiz Bay, SW Spain $\left(36^{\circ} 34.24^{\prime} \mathrm{N}, 06^{\circ} 14.19^{\prime} \mathrm{W}\right)$. The three specimens were maintained in a $2 \mathrm{~L}$ glass beaker, containing well-aerated filtered natural seawater (36) until hatching. No food was added. Females released larvae $72 \mathrm{~h}$ after their collection in several pulses for 24 $\mathrm{h}$, in a total amount of approximately 1600 larvae. After hatching, the most actively swimming larvae were gathered in only one pool. The larvae contained in the pool were then transferred to $1 \mathrm{~L}$ glass bottles (500 larvae per litre) with aeration at constant temperature $\left(20^{\circ} \mathrm{C} \pm 1\right)$ and fed with Artemia nauplii. The water was changed daily, and larvae were checked for evidence of moulting. Each time the water was renewed, 3-4 larvae were preserved in 4\% formalin. Rearing was terminated when larvae moulted to the megalopal stage.

Drawings and measurements were made with the aid of a camera lucida on a binocular Wild M8. Setal observations and drawings were made using a Zeiss microscope with camera lucida. The preparation of slides with appendages was temporary. Larval description followed the method proposed by Clark et al. (1998) and setal terminology was according to Ingle (1992). The aesthetascs of figures 3B' and 5B were drawn truncated to facilitate the illustration of the antennule. Similarly, the long plumose setae on maxilliped exopods in Figures 4F-G and on the pleopod exopods in Figures 6H-I are drawn truncated. Finally, the megalopal pereiopods are also drawn truncated in Figures 5A, 5A', and 6F. The setules from setae were omitted from drawings when necessary.

The sizes are given as the arithmetic mean $\pm 95 \%$ confidence intervals. Measurements taken in zoeal stages were: rostro-dorsal length (RDL) measured from tip of rostral spine to tip of dorsal spine; carapace length (CL) measured from base of rostrum (between the eyes) to posterolateral carapace margin; carapace width $(\mathrm{CW})$ the greatest distance across the carapace measured between the bases of carapace spines and, carapace width with lateral spines (CWls) measured between tips of lateral spines. In megalopa, total length (TL) is the distance from tip of rostrum to posterio-median margin of telson; carapace length (CL) is the distance from tip of rostrum to posterior margin of carapace; carapace width $(\mathrm{CW})$ is the carapace maximum width; propodus length (PL) from an imaginary line across the base of propodus to the distal margin, and dactylus length (DL) from an imaginary line across the base of dactylus to its distal end. The DL and PL measurement proportion of the 
first pereiopod of the megalopa is presented, because in the future it might be useful for phylogenetic and systematic purposes.

The complete larval series has been deposited in the Instituto Nacional de Recursos Biológicos (IPIMAR) in Lisbon, Portugal (number IPIMAR/L/In/02/2007).

\section{RESULTS}

Under laboratory conditions, the complete larval development of $I$. nucleus from hatching to megalopa took $32-38$ days at $20^{\circ} \mathrm{C}$. Four zoeal stages and one megalopa were obtained. The first zoeal stage and the megalopa are fully described, whereas for the second to fourth zoeae only the differences from previous stages are described in detail.

\section{Ilia nucleus (Linnaeus, 1758)}

(Figs. 1-6)

\section{First zoea (Fig. 1)}

Dimensions: $\mathrm{RDL}=1.436 \pm 0.041 \mathrm{~mm} ; \mathrm{CL}=$ $0.548 \pm 0.013 \mathrm{~mm} ; \mathrm{CW}=0.400 \pm 0.010 \mathrm{~mm} ; \mathrm{CWls}=$ $0.856 \pm 0.056 \mathrm{~mm}$.

Carapace (Figs. 1A, A'): globose and smooth. Dorsal spine present, long, stout and straight; rostral spine present inward curving, almost as long as dorsal spine; well developed lateral spines, with half the length of rostrum, backwards curving. One pair of dorsolateral setae present. Ventral margin of carapace without any seta. Eyes sessile.

Antennule (Fig. 1B): uniramous, unsegmented, conical shaped. With 4 aesthetascs and 1 short simple seta terminally.

Antenna (Fig. 1B): present as a very small bud.

Mandible (Fig. 1C): asymmetrical, palp absent. Incisor and molar processes differentiated.

Maxillule (Fig. 1D): coxal endite with 5-6 setae (1 simple and 4-5 papposerrate setae); basial endite with 4 strong ( 3 papposerrate and 1 serrulate) and 1 simple seta. Endopod unsegmented, with 4 terminal setae. Microtrichia as illustrated. Exopod seta absent.

Maxilla (Fig. 1E): coxal endite bilobed with $3+2$ sparsely papposerrate setae, basial endite bilobed with 4+4 sparsely papposerrate setae. Endopod unsegmented with $2+2$ pappose setae and microtrichia on inner and outer margin. Scaphognathite with 4 marginal plumose setae and a long setose posterior process. Microtrichia arranged as figured.

First maxilliped (Fig. 1F): coxa with 1 seta; basis with 8 medial setae arranged $2+2+2+2$ on the ventral side; endopod 5-segmented with 2, 2, 1, 2, 5 (one subterminal and four terminal) setae. Exopod unsegmented, bearing 4 long plumose natatory setae terminally.

Second maxilliped (Figs. 1G, G'): coxa without setae; basis with 4 medial setae arranged $1+1+1+1$ on the inner side; endopod unsegmented with 3 (one subterminal and two terminal) setae. Exopod unsegmented, bearing 4 long plumose natatory setae terminally.

Third maxilliped and pereiopods: absent.

Abdomen (Fig. 1H): 5 somites. A pair of dorsolateral processes on the posterior margin of somite 2 , and another pair in the median portion of somite 3 . Somites 2-5 with a pair of pappose dorso-marginal setae each.

Pleopods: absent.

Telson (Figs. 1H, H', H')): subtriangular, posterio-external angles each with one small furcal spine and with 6 setae on posterior margin, the central ones being the longest.

\section{Second zoea (Fig. 2)}

Dimensions: $\mathrm{RDL}=2.440 \pm 0.160 \mathrm{~mm} ; \mathrm{CL}=$ $0.818 \pm 0.055 \mathrm{~mm} ; \mathrm{CW}=0.608 \pm 0.059 \mathrm{~mm} ; \mathrm{CWls}=$ $1.598 \pm 0.188 \mathrm{~mm}$.

Carapace (Fig. 2A): dorsal spine as long as rostral spine and lateral spines unchanged. Eyes stalked.

Antennule (Fig. 2B): unchanged besides size.

Antenna (Fig. 2B): unsegmented rounded bud.

Mandible (Fig. 2C): unchanged besides size.

Maxillule (Fig. 2D): coxal endite with 7 setae (1 simple and 6 papposerrate setae); basial endite with 8 strong (7 papposerrate and 1 serrulate) and 1 simple seta. Exopod pappose seta present on outer margin.

Maxilla (Fig. 2E): coxal endite bilobed with $3+3$ sparsely papposerrate setae, basial endite bilobed with $5+4$ sparsely papposerrate setae. Scaphognathite with 20-21 marginal plumose setae.

First maxilliped (Fig. 2F): exopod unsegmented, bearing 6 long plumose natatory setae terminally.

Second maxilliped (Fig. 2G): exopod unsegmented, bearing 6 long plumose natatory setae terminally.

Third maxilliped (Fig. 2H): present as bud.

Pereiopods (Fig. 2I): present as undifferentiated buds.

Abdomen (Fig. 2J): first somite with 4-5 pappose 


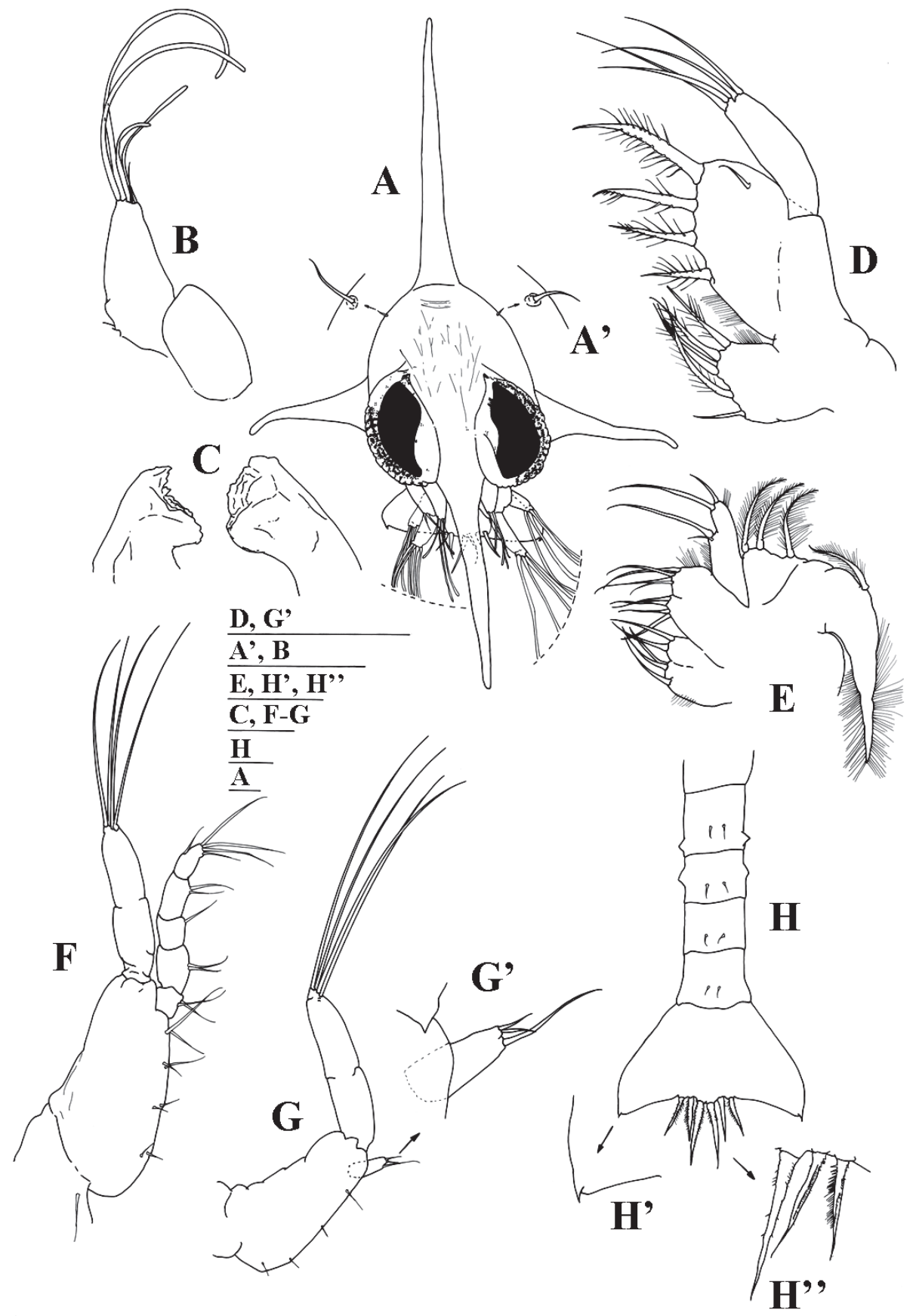

FIG. 1. - Ilia nucleus. First zoea: A, general aspect, frontal view; A', detail of setae on carapace; B, antennule and antenna; C, mandibles; D, maxillule; E, maxilla; F, first maxilliped; G, second maxilliped; G', detail of second maxilliped endopod; H, dorsal view of abdomen and telson; H', detail of furcal spine; $\mathrm{H}^{\prime}$, detail of furcal setae. Scale bars: $0.1 \mathrm{~mm}$

setae as illustrated.

Pleopods: absent.

Telson (Fig. 2J): unchanged.

\section{Third zoea (Fig. 3)}

Dimensions: $\mathrm{RDL}=3.154 \pm 0.092 \mathrm{~mm} ; \mathrm{CL}=$ $1.081 \pm 0.025 \mathrm{~mm} ; \mathrm{CW}=0.842 \pm 0.035 \mathrm{~mm} ; \mathrm{CWls}=$ $2.131 \pm 0.080 \mathrm{~mm}$.
Carapace (Fig. 3A): rostral spine measuring approximately two thirds of dorsal spine length; lateral spines almost as long as rostrum.

Antennule (Figs. 3B, B'): endopod present as a small bud; exopod with 6 aesthetascs arranged 1 subterminal and 5 terminal, and 1 simple seta terminally.

Antenna (Fig. 3B): endopod bud present.

Mandible (Fig. 3C): unchanged besides size. 


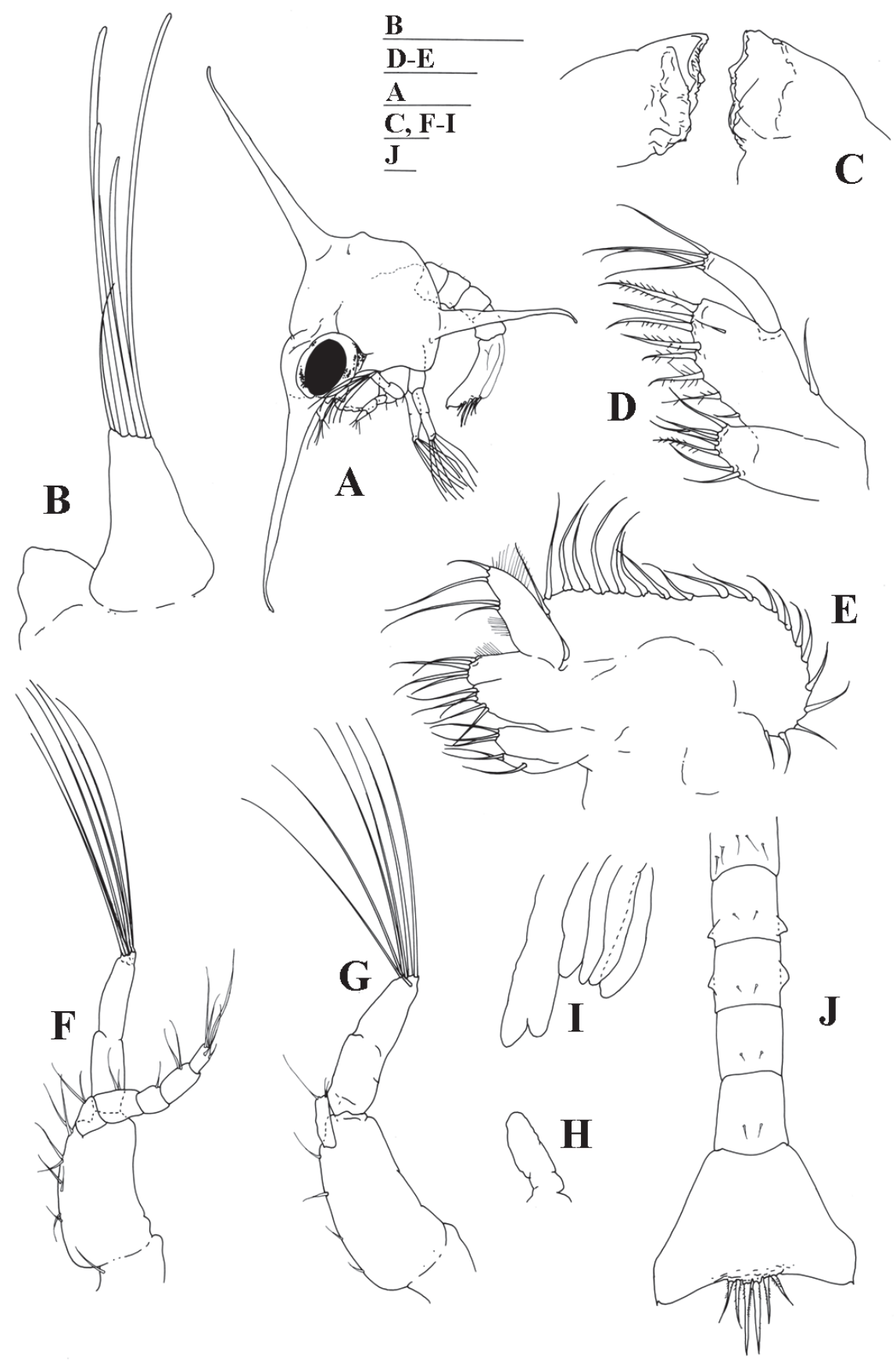

FIG. 2. - Ilia nucleus. Second zoea: A, general aspect, lateral view; B, antennule and antenna; C, mandibles; D, maxillule; E, maxilla; F, first maxilliped; G, second maxilliped; H, third maxilliped; I, pereiopods; J, dorsal view of abdomen and telson. Scale bars: $0.5 \mathrm{~mm}$ (A); $0.1 \mathrm{~mm}$ (B-J).

Maxillule (Fig. 3D): coxal endite with 6-7 setae (1 simple and 5-6 papposerrate setae); basial endite with 9-11 strong (7-9 papposerrate and 2 serrulate) and 1 simple seta.

Maxilla (Fig. 3E): basial endite bilobed with 5+4-5 sparsely papposerrate setae. Scaphognathite with 30-33 marginal plumose setae.

First maxilliped (Fig. 3F): exopod unsegmented, bearing 8 long plumose natatory setae terminally.
Second maxilliped (Fig. 3G): exopod unsegmented, bearing 8 long plumose natatory setae terminally.

Third maxilliped (Fig. 3H): biramous unsegmented bud. Epipodite present as a very small bud.

Pereiopods (Fig. 3I): elongated. Chelipeds bilobed and pereiopods unsegmented.

Abdomen (Fig. 3J): first somite with 6 dorsal pappose setae; somites 2-5 with a pair of posterodorsal 


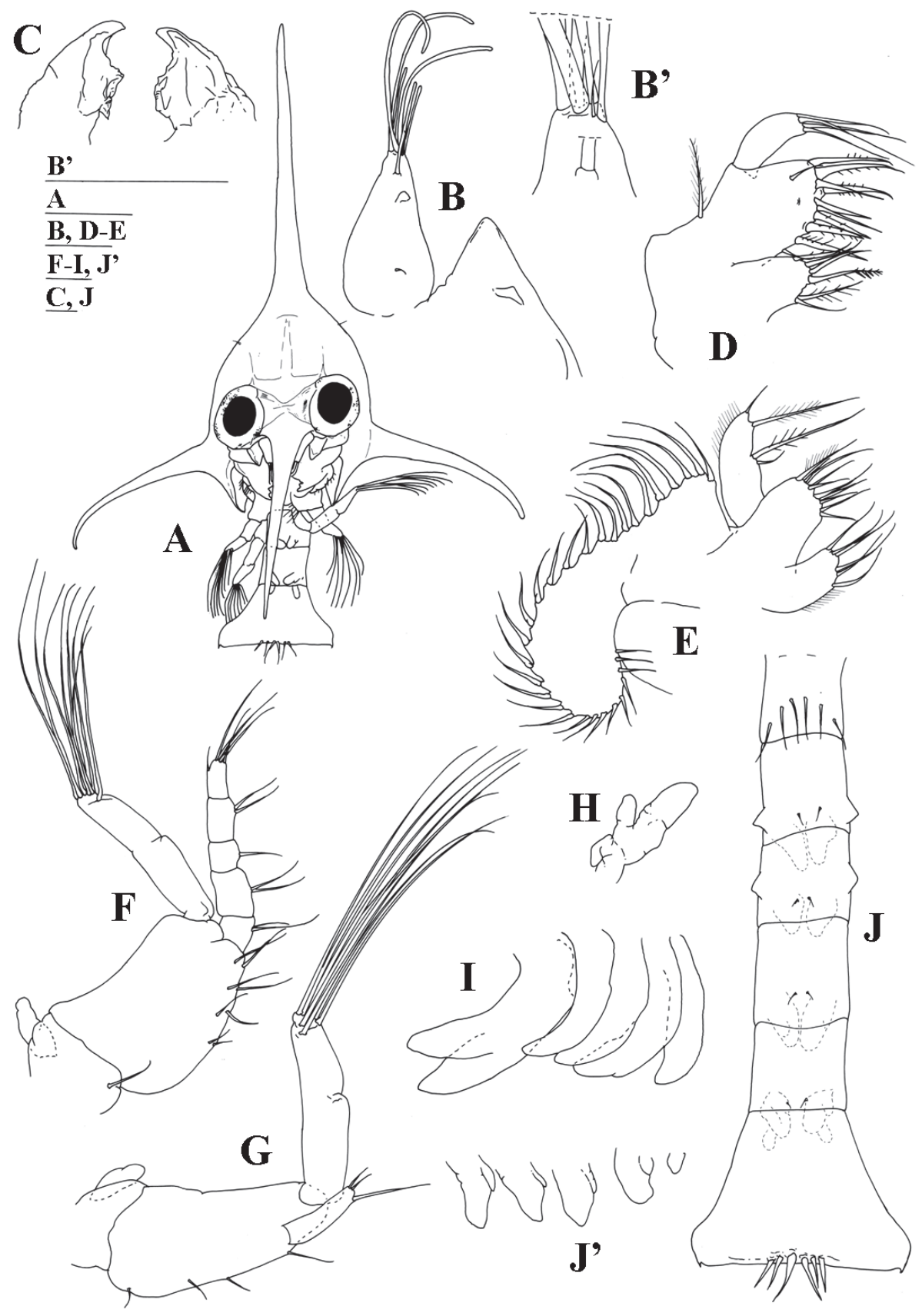

FIG. 3. - Ilia nucleus. Third zoea: A, general aspect, frontal view; B, antennule and antenna; B', detail of terminal aesthetascs and seta; C, mandibles; D, maxillule; E, maxilla; F, first maxilliped; G, second maxilliped; H, third maxilliped; I, pereiopods; J, dorsal view of abdomen and telson; J', pleopods. Scale bars: $0.1 \mathrm{~mm}$.

setae each.

Pleopods (Fig. 3J'): second to fifth pleopods present as small biramous buds; sixth pleopod very small, hidden at the base of the telson.

Telson (Fig. 3J): unchanged besides size.

\section{Fourth zoea (Fig. 4)}

Dimensions: $\mathrm{RDL}=3.589 \pm 0.182 \mathrm{~mm} ; \mathrm{CL}=$
$1.243 \pm 0.035 \mathrm{~mm} ; \mathrm{CW}=1.065 \pm 0.042 \mathrm{~mm} ; \mathrm{CWls}=$ $2.647 \pm 0.185 \mathrm{~mm}$.

Carapace (Fig. 4A): unchanged besides size.

Antennule (Fig. 4B): endopod bud enlarged; exopod with 10 aesthetascs arranged $2+4$ subterminal and 4 terminal and 1 simple seta terminally.

Antenna (Fig. 4B): enlarged in size.

Mandible (Fig. 4C): palp bud present.

Maxillule (Fig. 4D): coxal endite with 7-8 setae 


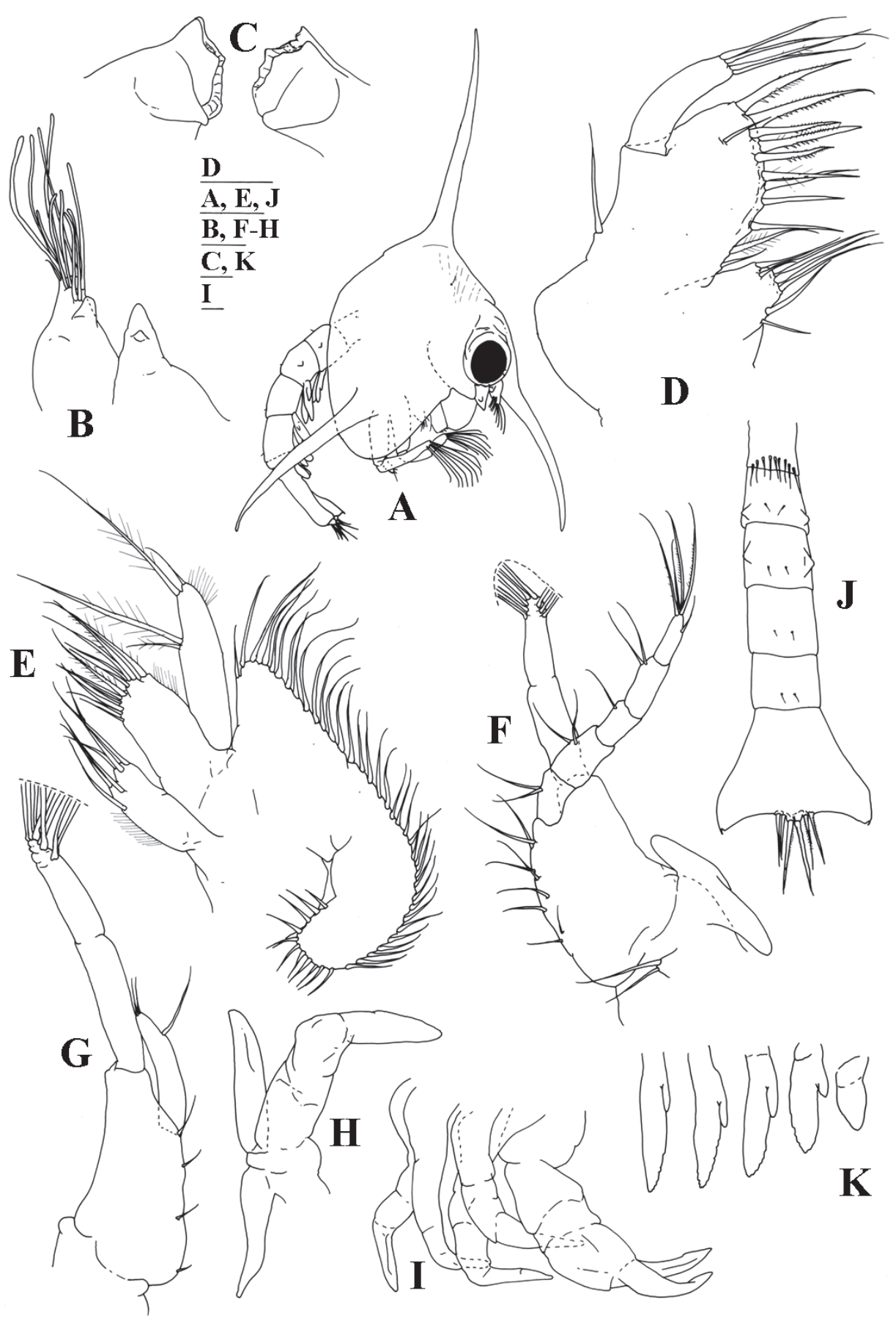

FIG. 4. - Ilia nucleus. Fourth zoea: A, general aspect, lateral view; B, antennule and antenna; C, mandibles; D, maxillule; E, maxilla; F, first maxilliped; G, second maxilliped; H, third maxilliped; I, pereiopods; J, dorsal view of abdomen and telson; K, pleopods. Scale bars: 0.5 mm $(\mathrm{A}, \mathrm{J}) ; 0.1 \mathrm{~mm}(\mathrm{~B}-\mathrm{I}, \mathrm{K})$.

(1 simple and 6-7 papposerrate setae); basial endite with 11-12 strong (8-9 papposerrate and 3 serrulate) and 1 simple seta.

Maxilla (Fig. 4E): basial endite with 6-5+6-5 sparsely papposerrate setae. Scaphognathite with 4046 marginal plumose setae. Microtrichia as figured.

First maxilliped (Fig. 4F): coxa with 2 setae.
Exopod unsegmented, bearing 8 long plumose natatory setae terminally.

Second maxilliped (Fig. 4G): exopod unsegmented, bearing 8 long plumose natatory setae terminally.

Third maxilliped (Fig. 4H): lobes of epipod, endopod and exopod enlarged. 


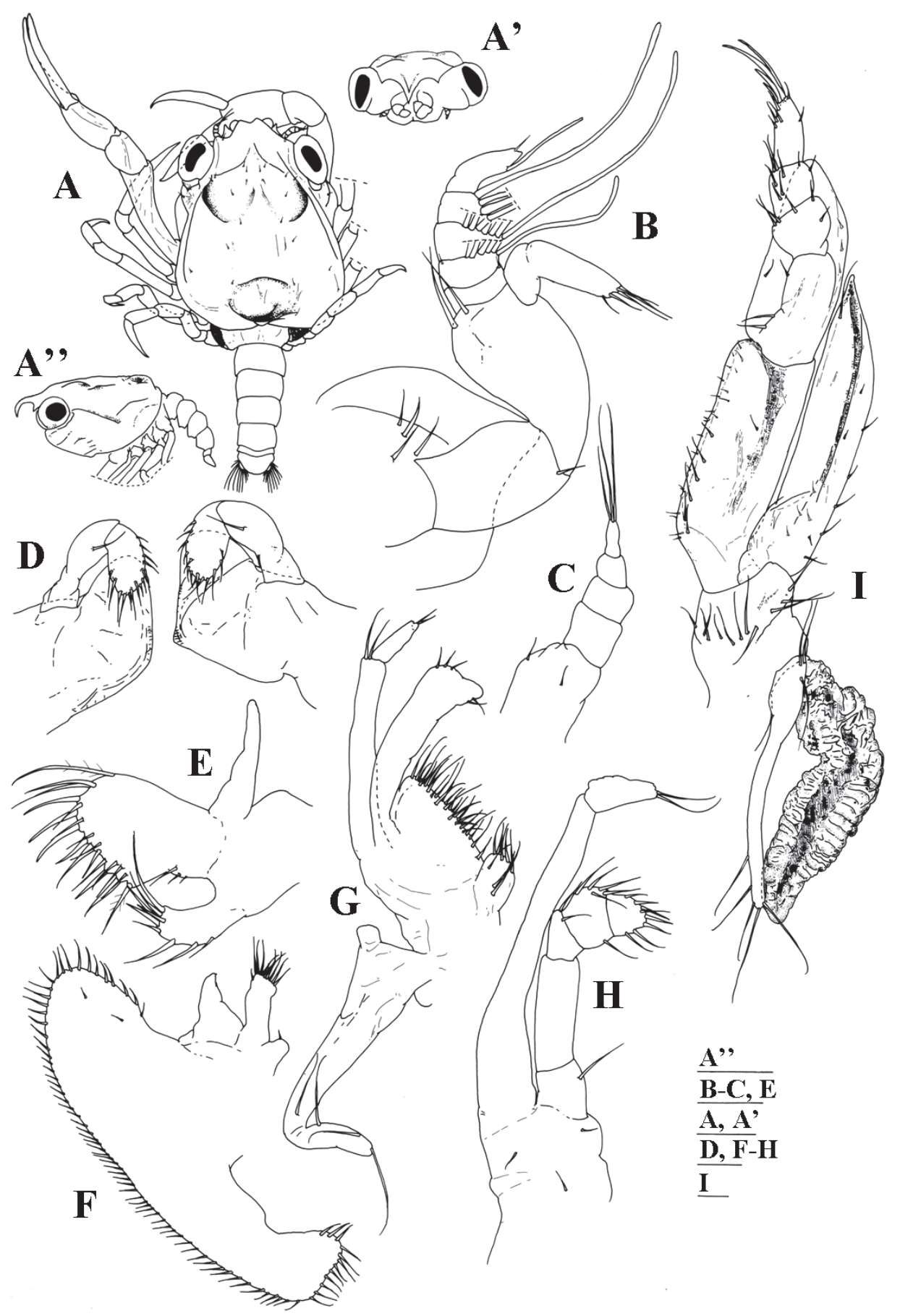

FIG. 5. - Ilia nucleus. Megalopa: A, general aspect, dorsal view; A', detail of frontal view of the rostrum; A', general aspect, lateral view; B, antennule; C, antenna; D, mandibles; E, maxillule; F, maxilla; G, first maxilliped; H, second maxilliped; I, third maxilliped. Scale bars: 1.0 $\mathrm{mm}(\mathrm{A}$ "); $0.1 \mathrm{~mm}(\mathrm{~A}-\mathrm{I})$.

Pereiopods (Fig. 4I): chelipeds and pereiopods 2-5 more developed and feebly segmented.

Abdomen (Fig. 4J): first somite with 9 dorsal pappose setae.

Pleopods (Fig. 4K): pleopod buds more developed in somites 2-5. Sixth pleopod bud uniramous.

Telson (Fig. 4J): unchanged besides size.
Megalopa (Figs. 5, 6)

Dimensions: $\mathrm{TL}=2.781 \pm 0.077 \mathrm{~mm} ; \mathrm{CL}=1.754$ $\pm 0.057 \mathrm{~mm} ; \mathrm{CW}=1.369 \pm 0.075 \mathrm{~mm}$.

Carapace (Figs. 5A, 5A', 5A'"): rectangular, convex on lateral margins. Rostrum directed obliquely downward, very small; frontal region broad. Submedian lobes hardly developed; hepatic region swollen; 


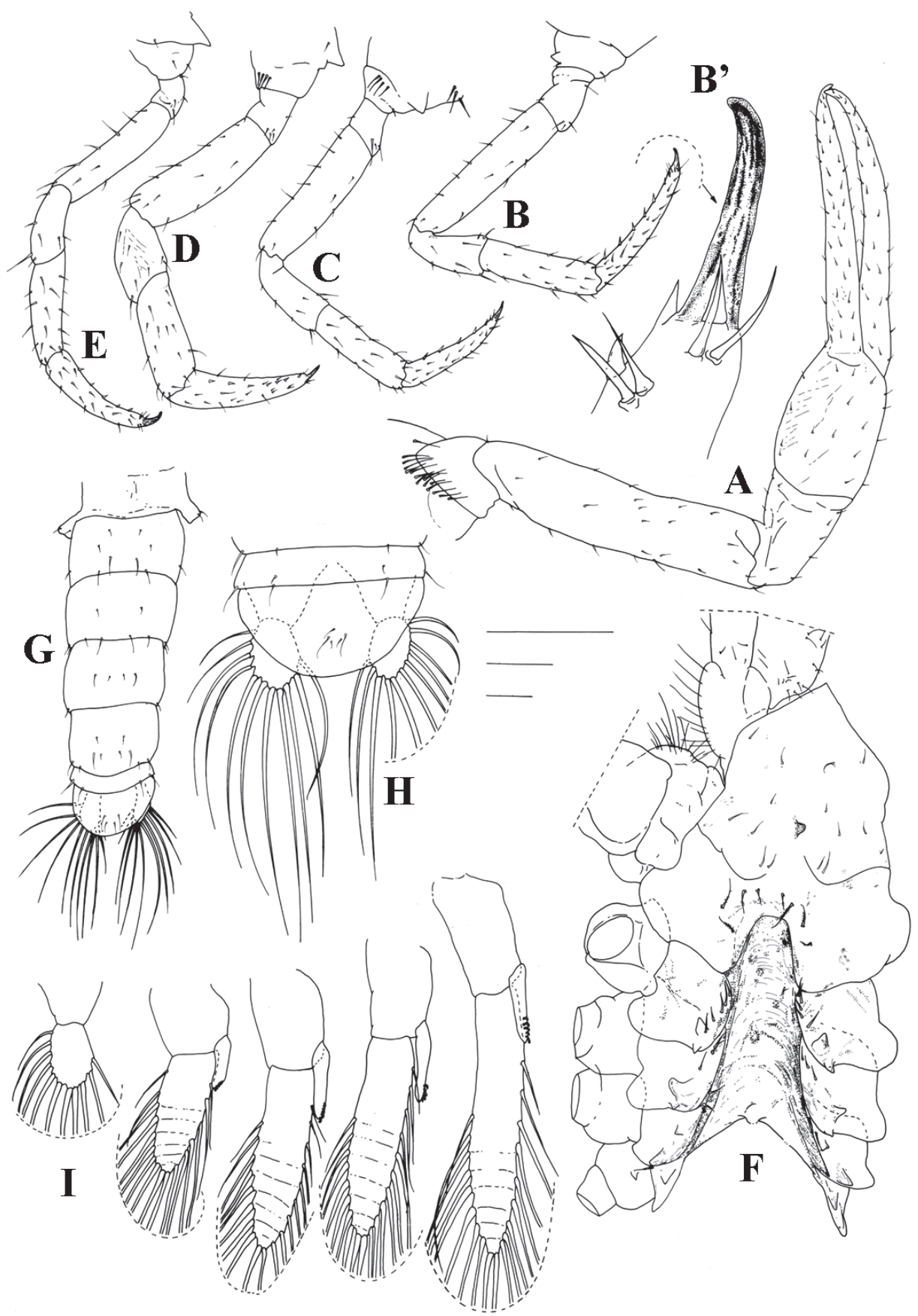

FIG. 6. - Ilia nucleus. Megalopa: A, first pereiopod; B, second pereiopod; B', detail of dactylus of second pereiopod; C, third pereiopod; D, fourth pereiopod; E, fifth pereiopod; F, sternum; G, dorsal view of abdomen and telson; H, telson and uropods; I, pleopods. Scale bars: 0.5 mm (A-E, G); 0.1 mm (B', F, H-I).

a pair of epibranchial-mesobranchial carinae; a cardiac swelling and an intestinal tubercle developed. Setae distributed as illustrated.

Antennule (Fig. 5B): peduncle 3-segmented, basal segment with 4 , middle segment with 1 and distal segment with 2-3 setae respectively. Endopod margin with 1 subterminal and 4 terminal (arranged $1+3$ ) simple setae. Exopod 5-segmented with 1 seta, 1 seta+ 6 aesthetascs, 1 seta+ 7 aesthetascs, 4 aesthetascs, and 1 subterminal aesthetasc +1 terminal seta.

Antenna (Fig. 5C): peduncle unsegmented with two simple setae and with the shortened exopod process; flagellum 4-segmented, segments first to fourth progressing proximally to distally, each with $0,0,0,3$ terminal (one shorter and two longer) simple setae. 
Mandibles (Fig. 5D): asymmetric, with a broad plate-shaped incisor process with an acute inner margin; palp 2-segmented, first segment with 1 simple seta, distal segment with 13-14 papposerrate setae.

Maxillule (Fig. 5E): coxal endite with 8-10 papposerrate setae; basial endite with 20-24 papposerrate setae. Endopod unsegmented without any seta.

Maxilla (Fig. 5F): coxal endite with one seta; basial endite with 5+4-5 setae. Endopod unsegmented without any seta. Scaphognathite with 75-82 marginal plumose setae and blade with 2-3 simple setae.

First maxilliped (Fig. 5G): coxa with 7-9 setae; basis with 27-30 setae. Endopod unsegmented with 5 setae. Exopod 2-segmented with 2 plumose setae on proximal segment, and 2 setae on distal segment. Epipod with 4-5 setae.

Second maxilliped (Fig. 5H): coxa with 1-2 setae; basis with 1-3 setae. Endopod 5-segmented with 1, 0, 2, 5-6 and 6-8 papposerrate setae, respectively. Exopod 2-segmented, first segment without setae, distal segment with 2 plumose setae.

Third maxilliped (Fig. 5I): arthrobranch and podobranch gill buds present; coxa with 10-12 setae; basis not clearly differentiated with 2 setae. Endopod 5-segmented, with 28-31, 8-10, 5-6, 8-10 and 10-12 setae, respectively. Exopod reduced to a single segment with 12 or 14 setae. Epipod elongated with 7-8 setae.

Pereiopods (Figs. 6A-E): all segments well differentiated, with setae as figured. Chelipeds equal, with a slender dactylus longer than the palm $(\mathrm{D} / \mathrm{P}=0.54$ 0.68). Pereiopods $2-5$ long, with sharp dactyls.

Sternum (Fig. 6F): maxillipeds and cheliped sternites fused with 10-11 pairs of setae and one medial small process; sternites of pereiopods 2-5 with 5-6, 3-5, 2 and 1 setae and 2 broad protuberance each which progressively become smaller anteriorly.

Abdomen (Figs. 5A, 5A', 6G): six somites, broader than long, with well developed tergites. Somites 1-6 proximally to distally with $4,10,10$, 10,10 and 8 simple setae dorsally and laterally distributed.

Pleopods (Figs. 6H, I): biramous, well developed decreasing in size from $1^{\text {st }}$ to $4^{\text {th }}$. Endopod unsegmented with 5-6, 4-6, 4-6 and 4-5 distal cincinuli on outer margin respectively. Exopod unsegmented with 19-20, 19-20, 18-19 and 16-18 marginal plumose natatory setae respectively. Uropods lacking endopod, 2-segmented, proximal segment (protopod) without setae, and distal segment (exopod) with 11-12 marginal plumose natatory setae.
Telson (Figs. 6G, H): broad, rounded posterior margin, with 2 pairs of simple setae on dorsal surface.

\section{DISCUSSION}

The morphological features of the zoeal stages of Ilia nucleus fit in the characters proposed by Rice (1980) for the family Leucosiidae: 4 zoeal stages; a globose carapace that may have dorsal, lateral and rostral spines, as in the genera Persephona, Arcania, Myra and Ilia, or all spines absent as in the Ebalia species, or almost all the variations between these for the other genera; antenna reduced to a bud without setae; maxillule endopod unsegmented bearing 4 terminal setae and maxilla endopod with 4 setae; first maxilliped endopod with 2, 2, 1, 2 and 5 setae; second maxilliped basis with 4 setae and endopod unsegmented with 3 setae; abdomen with 5 somites in all stages, somites 2 and 3 with small dorso-lateral knobs, and pleopods appearing in the third stage; subtriangular telson with posterioexternal angles each with one small furcal spine. Correspondingly, the larval stages of I. nucleus described in the present study are very similar to the described by previous authors (Cano, 1891; Boraschi, 1921; Bourdillon-Casanova, 1960; Heegard, 1963). The features observed coincide well with Heegard's description (1963), showing only minor differences. However some features pointed out by Heegard, such as a bifurcated antenna and the lack of one seta on the endopod of the maxilla (the author describes $2+1$ setae instead of $2+2$ ), differ from those described in the present work. This fact can be explained by differences in specimen preparation or by the precision of the optical observations.

In the northeastern Atlantic and Mediterranean Sea it has been considered that the family Leucosiidae is represented by the subfamilies Iliinae, Leucosiinae, and Ebaliinae (see Zariquiey-Álvarez, 1968), with Ilia nucleus included in the subfamily Iliinae. However, based on adult morphology, $\mathrm{Ng}$ et al. (2008) recently proposed a new classification of the family Leucosiidae. The family Leucosiidae is therefore presently represented by subfamilies Cryptocneminae, Ebaliinae and Leucosiinae (until now no larvae have been described for the first subfamily). These authors have discussed the general consensus that Leucosiidae has 4 or 5 subfamilies: 
Cryptocneminae, Leucosiinae, Ebaliinae, Philyrinae and perhaps Iliinae (the latter being the only one with a wholly Atlantic distribution). However, considering that Ebalinae, Philyrinae and Iliinae were not well defined, they decided to include all genera from these three groups in the subfamily Ebaliinae due to the seniority of this name until a complete generic reappraisal could be conducted.

Nevertheless, Ko (2000) considered I. nucleus within subfamily Philyrinae and separated this subfamily into 4 different groups, taking as distinctive characters the presence of dorsal, lateral and rostral spines of the carapace, the number of setae on the endopod of maxilla, and the number of spines on the posterolateral telson margin. The 4 groups considered by the author were formed by Persephona, Arcania and Myra genera in the first group, the single genus Ilia in the second group, and the species included in the Philyra genus were separated in the third and fourth groups. The assignment of the genus Ilia to Ko's second group was based on the description of Heegard (1963), who considered the presence of $2+1$ setae on the endopod of maxilla. However, the present study shows that I. nucleus larvae have $2+2$ setae on the endopod of the maxilla, a character that would include this species in the first group. In fact, I. nucleus zoeal stages are very similar to those defined by Ko (2000) for the first group of Philyrinae, having all carapace spines; 4 setae on maxillule endopod, 4 and 5-6 setae on maxillule basial and coxal endites, respectively; $2+2$ setae on maxilla endopod; and one spine on posterolateral telson margin. This first group of larvae was considered by Ko (2000) to be the most ancestral group in the Leucosiidae family, and providing the same group of characters I. nucleus would also be classified as an ancestral species in the family.

Also, the megalopa shows the typical characteristics of a leucosiid crab according to Quintana (1986): a smooth carapace with dorsal regions slightly swollen, a rudimentary rostrum, and 2 broad protuberances on sternites 2-4. Even though the significance of antennular armature seems to be unclear, Quintana (1986) stated that Leucosiidae megalopae could be divided into three subfamilies (Ebaliinae, Philyrinae and Leucosiinae) according to the segmentation and armature of the antennule outer flagellum, a consistent character at the subfamily level. The megalopa of I. nucleus has a 5-segmented antennular outer flagellum, aesthetascs in the terminal segment in a subterminal position, and the highest number of aesthetascs observed in the family (a total of 18), which according to Quintana (1986) place it in the Ebaliinae, and also agrees with the recent classification of $\mathrm{Ng}$ et al. (2008). Taking into account the number of aesthetascs, I. nucleus is more closely related to the Arcania, Myra and Philyra group, identified as Philyrinae by Quintana (1986), since these exhibit 16-17 aesthetascs in the antennular flagellum. These results are coherent with $\mathrm{Ng}$ et al. (2008), once the Ebaliinae subfamily had been synonymised with the Philyrinae. We can state that the megalopa of Ebaliinae has a 3- to 5-segmented antennular flagellum, the aesthetascs on distal segment can be absent or present, and the total number of aesthetascs varies among 5-18.

Larval morphological characters are useful for species to infer phylogenetic relationships. Hence, Quintana (1986) assumed that characters exhibited by megalopae belonging to Ebalia and Nucia were plesiomorphic, the subfamily Ebaliinae being the most primitive leucosiid group, and consequently the Leucosia species (subfamily Leucosiinae) should be the apomorphic group. However, the inferences about the phylogenetic position considering the megalopal stage will also define I. nucleus as the most primitive among the Ebaliinae. $\mathrm{As} \mathrm{Ng}$ et al. (2008) affirmed, the actual subfamily Ebaliinae is a very heterogeneous group and considering the larval characters, it includes the most ancestral species in the Leucosiidae and also the most derived ones.

Finally, I. nucleus shows eight natatory setae on the exopod of the maxillipeds in the third and fourth zoeal stages. Nevertheless, the typical sequence of the number of natatory plumose setae on maxillipeds exopods in Brachyura larval series with four zoeal stages is: four setae in the first zoea, six in the second, eight in the third and ten in the fourth. As in I. nucleus, Jorgensen (1925) described analogous results for Ebalia sp., presenting the sequence of zoea II to IV with 6 natatory plumose setae on maxilliped exopods. Lebour (1928) described Ebalia tuberosa with six natatory plumose setae on maxilliped exopods in the second and third zoeae, and eight in fourth zoea. He concluded that eight setae on maxilliped exopods in the fourth zoeal stage was a particular feature of Ebalia, as did Salman (1982) when studying the larval development of this genus. Other authors (e.g. Krishnan and Kannupandi, 1990) described Philyra globosa as having 4, 6 and 6 plumose natatory setae on maxilliped exopods in 
the first to third zoeae; Ko $(2000,2001)$ described $P$. platychira and $P$. kanekoi respectively with 4, 6 and 6 setae through zoeal stages; and Ghory and Siddiqui (2008) described Leucosia aff. biannulata and Philyra aff. platychira as having 6 setae on maxilliped exopods in the third zoeal stage. However, Negreiros-Fransozo et al. (1989) described the normal sequence (4, 6, 8 and 10 setae) for Persephona mediterranea zoeal stages. Consequently, in leucosiid crab zoeal stages a first zoea always has 4 plumose natatory setae on the maxilliped exopods, a second zoea always has 6 , a third zoea can have 6 or 8 , and a fourth zoeal stage has 8 or 10 plumose natatory exopod setae. As a result, we suggest that for the correct identification of a zoeal stage of a leucosiid, besides counting the number of setae on maxilliped exopods, the antennule development as well as the pereiopods development should be used as additional characters.

Taking into account that Leucosiinae and Ebaliinae are the only subfamilies with their larvae known, and identifying the heterogeneity in Ebaliinae, we are of the opinion that the present larval morphology conclusions do not give many clarifications to the current Code, and a complete generic reappraisal is perhaps still needed. More larval descriptions of Leucosiidae genera and species are needed. The present work describes the $16^{\text {th }}$ leucosiid megalopae, and in the last 20 years Negreiros-Fransozo et al. (1989) and Ko (2000) were the only publications that presented the complete larval development of species of this family. As Rice (1980) and Quintana (1986) stated, the development of the Leucosiidae is still very poorly known and the information of their zoeal and megalopal morphology would be significantly modified as further information becomes available.

\section{ACKNOWLEDGEMENTS}

CB was funded by the FCT (Portuguese Foundation for Science and Technology) doctoral fellowship (SFRH/BD/16695/2004). JIGG was funded by the Spanish Science and Technology Ministry and the ERDF through the Ramón y Cajal Research Programme.

\section{REFERENCES}

Boraschi, L. - 1921. Osservazione sulle larve dei Crostacei Decapodi: brachyuri e anomuri. Mem. R. Com. Talassogr. Ital., 87: $1-32$.

Bourdillon-Casanova, L. - 1960. Le meroplancton du Golfe de Marseille: les larves de crustacés décapodes. Rec. Trav. Stat. Mar. Endoume, 30(18): 1-286.

Cano, G. - 1891. Sviluppo postembrionale dei Dorippidei, Leucosiadi, Corystoidei e Grapsidi. Mem. Soc. Ital. Sci. Nat., 8(4): $1-14$.

Caroli, E. - 1921. Sullo svillupo larvale dei Crostacei Decapodi. Monit. Zool. Ital. Firenze (Rend. Union. Zool. Ital. Trieste), 32: 16-18.

Clark, P.F., D.K. Calazans and G.W. Pohle. - 1998. Accuracy and standardization of brachyuran larval descriptions. Inv. Rep. Dev., 33: 127-144.

d'Udekem d'Acoz, C. - 1999. Inventaire et distribution des crustacés décapodes de l'Atlantique nord-oriental, de la Méditerranée et des eaux continentales adjacentes au nord de $25^{\circ} \mathrm{N}$. Collection Patrimoines Naturels (MNHN/SPN), 40: 1-383.

Ghory, F.S. and F.A. Siddiqui. - 2008. Description of Leucosiidae (Crustacea: Brachyura) larval stages collected from the Manora Channel, Pakistan, during 1993-1995. Pakistan J. Zool., 40(5): 353-363.

González-Gordillo, J.I., A. dos Santos and A. Rodríguez. - 2001. Checklist and annotated bibliography of decapod crustacean larvae from the Southwestern Europe coast (Gibraltar Strait area). Sci. Mar., 65(4): 275-305.

Heegard, P. - 1963. Decapod larvae from the Gulf of Napoli hatched in captivity. Vid. Medd. Dansk. Nat. For., 125: 449-493.

Ingle, R.W. - 1992. Larval stages of Northeastern Atlantic crabs. An illustrated key. Chapman and Hall, London.

Jorgensen, O.M. - 1925. Some Crustacean Larvae from the Northumberland Plankton. Trans. Nat. Hist. Soc. Northumb., 6: 157-166.

Ko, H.S. - 2000. Larval development of Philyra platychira (Decapoda: Leucosiidae) reared in the laboratory. J. Crustac. Biol., 20(2): 309-319.

Ko, H.S. - 2001. Zoeal stages of Philyra kanekoi Sakai, 1934 (Crustacea: Decapoda: Leucosiidae) reared in the laboratory. Korean J. Biol. Sci., 5: 275-281.

Krishnan, T. and T. Kannupandi. - 1990. Larval and post-larval development of the purse crab Philyra globosa (Fabricius, 1888) (Decapoda: Brachyura: Leucosiidae) reared in the laboratory. Hydrobiologia, 190: 171-182.

Lebour, M.V. - 1928. Studies of the Plymouth Brachyura. II. The larval stages of Ebalia and Pinnotheres. J. Mar. Biol. Ass. U. K., 15: 109-123.

Negreiros-Fransozo, M.L., A. Fransozo and N.J. Hebling. - 1989. Larval development of Persephona mediterranea (Herbst, 1794) (Brachyura, Leucosiidae) under laboratory conditions. Crustac. Int. J. Crustac. Res., 57(2): 177-193.

Ng, P.K.L., D. Guinot and P.J.F. Davie. - 2008. Systema Brachyurorum: Part I. An annotated checklist of extant Brachyuran crabs of the world. Raffles Bull. Zool., 17: 1-286.

Quintana, R. - 1986. The megalopal stage in the Leucosiidae (Decapoda, Brachyura). Zool. Sci., 3: 533-542.

Rice, A.L. - 1980. The first zoeal stage of Ebalia nux A Milne Edwards 1883, with a discussion of the zoeal characters of the Leucosiidae (Crustacea, Decapoda, Brachyura). J. Nat. Hist., 14: 331-337.

Salman, S.D. - 1982. Observations on the larvae of the North European crabs of the genus Ebalia (Brachyura, Leucosiidae). Crustac. Int. J. Crustac. Res., 42(3): 256-269.

Zariquiey-Álvarez, R. - 1968. Crustáceos Decápodos Ibéricos. Invest. Pesq., 32: 1-510.

Scient. ed.: P. Abelló.

Received April 23, 2008. Accepted December 22, 2008.

Published online May 4, 2009. 